\title{
MHRA
}

Modern Humanities Research Association

Thomas Lodge as an Imitator of the Italian Poets

Author(s): L. E. Kastner

Reviewed work(s):

Source: The Modern Language Review, Vol. 2, No. 2 (Jan., 1907), pp. 155-161

Published by: Modern Humanities Research Association

Stable URL: http://www.jstor.org/stable/3713311

Accessed: 10/09/2012 03:19

Your use of the JSTOR archive indicates your acceptance of the Terms \& Conditions of Use, available at http://www.jstor.org/page/info/about/policies/terms.jsp

JSTOR is a not-for-profit service that helps scholars, researchers, and students discover, use, and build upon a wide range of content in a trusted digital archive. We use information technology and tools to increase productivity and facilitate new forms of scholarship. For more information about JSTOR, please contact support@jstor.org. 


\section{THOMAS LODGE AS AN IMITATOR OF THE ITALIAN POETS.}

THE extent of Lodge's indebtedness to the French poets of the sixteenth century, notably to Ronsard and Desportes, has already been pointed out-to a certain degree by $\mathrm{Mr} \mathrm{A}: \mathrm{H}$. Bullen in the Introduction (pp. vii-xv) to his Lyrics from Elizabethan Romances (1890), and more particularly by Mr Sidney Lee in the Introduction (pp. lxiv ff.) to Elizabethan Sonnets (1904), and lastly, by myself in the Athenaeum, No. 4017 (October 22, 1904). In the present note, I propose to show that Lodge did not confine his attention to the French poets, but was almost as fond of making raids on Italian as on French ground. I will take the sonnet-cycle Phillis, on which Lodge's fame as a poet has hitherto mainly rested, to exemplify my contention, hoping some day to show that the romances also were inspired in part by Italian models.

To begin with, sonnet XVII of Phillis ("Ah fleeting weale, ah slie deluding sleepe') is a close rendering of Sannazaro's 'Ahi letizia fugace, ahi sonno lieve,' as will be seen at once by placing the two en regard:

Ah fleeting weale, ah slie deluding sleepe,

That in one moment givest me ioye and paine:

How doe my hopes dissolue to teares in vaine?

As wount the Snowes, fore angrie sunne to weepe?

Ah noysome life that hath no weale in keepe,

My forward griefe hath forme and working might,

My pleasures like the shaddowes take their flight:
Ahi letizia fugace, ahi sonno lieve, Che mi dai gioja e pena in un momento :

Come le mie speranze hai sparte al vento,

E fatto ogni mia gloria al sol di neve?

Lasso, il mio viver sia nojoso e.greve;

Si profondo dolor nell' alma sento,

Ch'al mondo or non sarebbe uom si contento,

Se non fosse il mio ben stato si brieve. Felice Endimion, che la sua Diva

Sognando si gran tempo in braccio tenne ; 


\section{Thomas Lodge as an Imitator of the Italian Poets}

My pathe to blisse is tedious long and steepe.

Twise happie thou Endemion that embracest,

The liue-long night thy loue within thine armes:

Where thou fond dreame my longed weale defacest,

Whilest fleeting and vncertaine shaddes thou placest

Before my eies with false deluding charmes.

Ah instant sweetes which do my heart reuiue,

How should I ioy if you were true aliue?
E più, se al destar poi non gli fu schiva.

Che se d'un' ombra incerta e fuggitiva

Tal dolcezza in un punto al cor mi venne ;

Qual sarebbe ora averla vera e viva?

As Lodge copied a good many of his sonnets from Desportes, himself an inveterate plagiarist from the Italians, it might be supposed that Lodge's immediate source was Desportes and not Sannazaro. In the present case, however, there can be no doubt, as the sonnet of Sannazaro quoted above is not one of those appropriated by Desportes from the author of the Arcadia 1 .

Sonnet xxvi of Phillis ('Ile teach thee lovely Phillis, what loue is') is obviously an adaptation of Bembo's famous Capitolo: 'Amor e Donne care un vano e fello,' so frequently copied in the sixteenth century, while No. $x x v$ ('I wage the combat with two mightie foes') is clearly suggested by Petrarch's 'Due gran nemiche insieme erano aggiunte.'

Several of the Phillis sonnets are filched from the Rime volgari of Lodovico Paschale, published at Venice in 1549. This rather obscure Venetian appears to have been a favourite of Lodge, who incorporatedwith acknowledgements this time-one of his sonnets in A Margarite of America (1596). Mr Sidney Lee (op. cit., p. lxxiii) has already supposed that some of the sonnets to Phillis come from that source but as he gives no instances and the Rime of Paschale are extremely rare, I have thought it worth while to prove that three at least of Lodge's sonnets are drawn from the Italian poet.

In the first case (Phillis, No. II), the translation is fairly literal, in spite of a few changes in the proper names:

1 On Desportes' plagiarisms from the Italian poets ef. Francesco Flamini, Studi di storia letteraria italiana e straniera, Livorno, 1895, pp. 347-379, 433-439, who most appropriately describes Desportes as ' un poeta italiano camuffato alla francese.' 
You sacred Sea-nimphes pleasantly disporting,

Amidst this watrie world, where now I saile:

If euer loue, or louers sad reporting,

Had power sweet teares from your faire eyes to hayle:

And you more gentle-hearted then the rest,

Vnder the Northren Noon-stede sweetly streaming:

Lend those moyst riches of your christall crest,

To quench the flames from my hearts Etna steaming.

And thou kinde Triton in thy trompet relish,

The ruthfull accents of my discontent:

That midst this treauell desolate and hellish,

Some gentle winde that listens my lament

May prattle in the north in Phillis eares,

Where Phillis wants Damon consumes in teares.
Ninfe de'l mar che con soave errore Solcate l'onda placida e tranquilla Se mai d'amor sentiste in voi favilla Pietà vi mova il mio crudel dolore,

Et voi c'havete più benigno il core Vaga Arethusa e gratiosa Scilla

De'l vostro humor spargete qualche stilla

Ne'l vivo incendio de'l mio fiero ardore,

Et tu Triton nella tua cava tromba Queste parole con tal forza inspira Che la mia donna intenda l'alto grido, Il tuo, fidel; là dove il mar ribomba E'l vento freme e non si scerne il lido Di se non cura, e sol per te sospira.

In the second case (Phillis, No. vi) Lodge's rendering follows the Italian model more closely:

It is not death which wretched men call dying,

But that is very death which I endure:

When my coy looking Nimph (hir grace enuying,)

By fatall frownes my domage doth procure.

It is not life which we for life approue,

But that is life when on hir woul-soft pappes,

I seale sweet kisses, which do batten loue :

And doubling them do treble my good happes.

Tis neither loue the sonne, nor loue the mother,

Which louers praise and pray to; but that loue is,

Which she in eye and $I$ in heart do smother,

Then muse not tho I glory in my misse.

Since she who holdes my heart, and me in durance,

Hath life, death, loue and all in hir procureance.
Morte non è quel che morir s'appella Ma quella è vera morte ch'io supporto Quando Madonna di pietà rubella A me rivolge il guardo acerbo e torto,

Il viver non è vita, vita è quella Ch'io provo, se talhor, per mio conforto La Donna mia ch'è più d'ogn' altra bella,

Mi sia cortese d'un bel guardo accorto,

Amor non è quel ch'è d'amanti Duce

Amor è quel che da begl' occhi viene

Che m'han acceso il cor con la sua luce,

S'io dunque godo, in stracci affanni, e pene

Maraviglia non è, ch'à ciò m'induce

Chi Morte, Vita, Amor, ne gl'occhi tiene. 


\section{Thomas Lodge as an Imitator of the Italian Poets}

In the last case (Phillis, No. xvIII), the English poet is still more literal :

As where two raging venomes are vnited,

(Which of themselues disseuered life would seuer;)

The sickly wretch of sicknesse is acquited,

Which else should die, or pine in torments euer,

So fire, and frost, that holde my heart in seasure,

Restore those ruines which themselues haue wrought,

Where if a part they both had had their pleasure,

The earth long since, hir fatall claime had cought.

Thus two vnited deathes, keepe me from dying,

I burne in Ice, and quake amidst the fire:

No hope midest these exteames or fauour spyinge,

Thus loue makes me a Martir in his yre.

So that both colde and heate do rather feed,

My ceaslesse paines, then any comfort breede.

Qual duo Veneni uniti l'huom tal' ora

Soglion d'affanno trar, è di tormento,

Che se fusser disgiunti in un momento

Ogn' un di lor cagion di morte fora,

Tal, se mi strugge il foco; mi ristora

Quel freddo ghiaccio che ne'l petto sento,

Ch'ognun per se m'havria di vita spento

$\mathrm{Ma}$ fan due morti unite ch'io non mora,

Ardo ne'l ghiaccio e tremo in mezzo 'l foco

Tra duo contrarij mi tormenta Amore

Ne veder posso il fin di questo gioco,

$\mathrm{Ne}$ se ne'l ghiaccio son a tutte l'hore,

Ne s'ardo puo schemarsi molto o poco

Anzi più cresce ogn' hor il mio dolore.

Another favourite Italian poet of Lodge's was Lodovico Dolce, more famous in his day as a playwright and commentator than as a lyric poet. Lodge borrowed from him for his Margarite several sonnets and one lyric piece (a sestina, probably the earliest in English literature) which he describes as 'written in imitation of Dolce, the Italian poet.' Thus it might be supposed that Lodge utilized Dolce as well as Paschale. An examination of those of his sonnets (some four score)-which I have come across in the various Italian anthologies of the sixteenth century, has not confirmed that supposition, however, but as I was unable to lay my hands on the collected Rime of Dolce in any of the English libraries I consulted, it will be as well not to be too affirmative. Vincenzo Martelli, who is also quoted by Lodge in A Margarite of America, did not contribute the matter for any of the sonnets to Phillis, but a far greater poet than any of these, namely Lodovico Ariosto, served as the model for as many as five of the sonnets to Phillis. Leaving aside No. XxI ('Ye heraultes of my heart, mine ardent groanes'), already identified, I will content myself with printing the four following sonnets of Lodge, together with their originals in Ariosto. This course, better than any words, I venture to think, will enable the reader to appreciate the close dependence of Lodge on the author of Orlando Furioso: 
Phillis, $\mathrm{xx}$.

Some praise the lookes, and others praise the lockes,

Of their faire Queenes, in loue with curious wordes:

Some laud the breast where loue his treasure locks,

All like the eie that life and loue affordes.

But none of these fraile beauties and vnstable

Shall make my pen ryot in pompous stile :

More greater giftes shall my graue muse enable,

Whereat seuerer browes shall neuer smile.

I praise hir honny-sweeter eloquence,

Which from the fountaine of true wisdome floweth:

Hir modest meane that matcheth exelence,

Hir matchlesse faith which from hir vertue groweth:

And could my stile hir happie vertues equale,

Time had no power hir glories to enthrale.

\section{Phillis, xxII.}

Faire art thou Phillis, I so faire (sweet mayd)

As nor the sunne, nor I have seene more faire,

For in thy cheekes sweet roses are embayde,

And golde more pure than gold doth guilde thy haire.

Sweet Bees haue hiu'd their hony on thy tongue,

And Hebe spic't hir Necter with thy breath:

About thy necke do all the graces thronge,

And lay such baites as might entangle death.

In such a breast what heart would not be thrall?

From such sweet armes who would not wish embraces?

At thy faire handes who wonders not at all,

Wounder it selfe through ignorance embases ?

Yet naithelesse tho wonderous giftes you call these,

My faith is farre more wonderfull than all these.
Sonetto Xv.

Altri loderà il viso, altri le chiome Della sua donna, altri l'avorio bianco, Onde formò Natura il petto e'l fianco, Altri darà a'begli occhi eterno nome.

Me non bellezza corruttibil, come Uningegnodivino, ha mosso unquanco; Un animo cost libero e franco, Come non senta le corporee some;

Una chiara eloquenza che deriva $\mathrm{Da}$ un fonte di sapere; una onestade Di cortesi atti, $\theta$ leggiadria non schiva. Chè s'in me fosse l'arte alla bontade Della materia ugual, ne farei viva Statua che dureria più d'una etade.

\section{Sonetto XxV.}

Madonna, sete bella, e bella tanto, Ch'io non veggio di voi cosa più bella; Miri la fronte, o l'una e l'altra stella, Che mi scorgon la via col lume santo:

Miri la bocca, a cui sola do vanto, Che dolce ha il riso e dolce ha la favella ; E l'aureo crine, onde Amor fece quella Rete che mi fu tesa d'ogni canto:

$\mathrm{O}$ di terso alabastro il collo e'l seno, 0 braccio o rnano: e quanto finalmente Di voi si mira, e quanto se ne crede:

Tutto è mirabil certo: nondimeno Non stard ch'io non dica arditamente, Che più mirabil molto è la mia fede. 


$$
\text { Phillis, xxvir. }
$$

Faire eyes whilest fearefull I your faire admire,

By vnexpressed sweetnes that I gaine,

My memory of sorrow doth expire,

And faulcon like I tower ioyes heauens amaine :

But when yoursonnes in Oceans of their glory,

Shut vppe their day-bright shine, I dye for thought:

So passe my ioyes as doth a new plaid storie,

And one poore sigh breaths all delight to nought.

So to my selfe I liue not, but for you,

For you I liue, and you I loue, but none else :

Oh then faire eyes whose light I liue to viewe,

Or poore forlorne despis'd to liue alone els,

Looke sweete since from the pith of contemplation,

Loue gathereth life, and liuing, breedeth passion.

\section{Phillis, xxviII.}

Not causelesse were you christned (gentle flowers)

The one of faith, the other fancies pride,

For she who guides both faith and fancies power,

In your faire coloures wrapes hir Iuory side :

As one of you hath whitenes without staine,

So spotlesse is my loue and neuer tainted:

And as the other shadoweth faith againe,

Such is my lasse, with no fond chaunge acquainted:

And as nor tirant sonne nor winter weather,

May eeuer chaunge sweet Amaranthus hew :

So she tho loue and fortune ioyne together,

Will neuer leaue to bee both faire and true :

And should I leave thee then thou prettie elfe?

Nay first let Damon quite forget himselfe.

\section{Sonetto xvIr.}

Occhi miei belli, mentre ch'io vi miro, Per dolcezza ineffabil ch'io ne sento, Vola, come falcon ch'ha seco il vento, La memoria da me d'ogni martiro:

$\mathrm{E}$ tosto che da voi le luci giro, Amaricato resto in tal tormento, Che s'ebbi mai piacer, non lo rammento ;

$\mathrm{Ne}$ va il ricordo col primier sospiro.

Non sarei di vedervi già sì vago,

S'io sentissi giovar, come la vista, L'aver di voi nel cor sempre l'immago.

Invidia è ben, se'l guardar mio v'attrista ;

E tanto più che quell' ond'io m'appago, Nulla a voi perde, ed a me tanto acquista.

Sonetto vI.

Non senza causa il giglio e l'amaranto, L'uno di fede, e l'altro fior d'amore, Del bel leggiadro lor vago colore, Vergine illustre, v'orna il vostro manto. Candido e puro l'un mostra altrettanto In voi candore e purità di core; All' animo sublime l'altro fiore Di costanza real dà il pregio e il vanto. Com' egli al sole e al verno, fuor d'usanza

D'ogni altro germe, ancor che forza il sciolga

Dal natio umor, sempre vermiglio resta:

Cosl vostr' alta intezione onesta,

Perchè Fortuna la sua ruota volga

Come a lei par, non può mutar sembianza. 
If we add the above cases of plagiarism from the Italian poets to the numerous loans that Lodge has levied on Ronsard and Desportes, we come to the conclusion that of the thirty-eight poems of sonnet character contained in Phillis, twenty-four are filched from foreign sources, so that-leaving the few miscellaneous pieces and the annexed dreary and obscure Complaint of Elstred out of account-Phillis is little more than an exercise in translation from the French and the Italian, and one of the most impudent cases of literary 'larceny,' to use Puttenham's term, in the history of literature. In all probability time will disclose the source of the remaining fourteen sonnets.

L. E. Kastner. 